\title{
The Evolution of Federalism as a System of Governance in South Asia: A Historical Appraisal
}

\author{
Dr. Muhammad Reza Kazimi*
}

\begin{abstract}
Federation as a form of government evolved while seeking a balance between security and identity. Unitary states were the earliest and most natural form of government but after tribulations, it was discovered that they were not congruent to identity. The various sized of German and Italian principalities before their Nineteenth Century unification are an illustration. Throughout history, Europe has been seeking every option between a city-state and empire. America is an important stage because it had been a Confederation during its Freedom Struggle but later found Federation more feasible. In British India, federalism presented itself as a solution when the Congress wanted power to be located in the center and the Muslim League wanted it located in the provinces. The last such attempt, the Cabinet Mission Plano of 1946 having failed, Pakistan when independent opted for a federation because in the words of the first Prime Minister Liaquat Ali Khan: "Geography dictates it."
\end{abstract}

Key Words: Security, identity confederation, federation, The Christian Republic proposal

*Dr. Muhammad Reza Kazimi is Editor, Historicus The Quarterly Journal of the Pakistan Historical Society and earlier, Editorial Consultant , Oxford University Press (2000-2013) 


\section{Introduction}

Historically, federation is the most difficult form of government to achieve. Unitary states and confederations are always at hand, depending on how large or on how limited the membership is to be. On the other hand, political philosophies in South Asia have a long history. The Arthshastra of Kautilya mentions alliances and counter-alliances, but not federations. Later, Bana wrote a more pacifist tract in his biography of his royal patron Harsha Charitha. India with its vast land mass and diverse climatic regions needed an arrangement approximating to a federation, but could not envisage one. Since the invasion of Alexander, there began in India an alteration between paramount empires and fragmented kingdoms. The Maurya Empire was succeeded by small kingdoms, as was the Gupta Empire. Muslim rule did not break the momentum of this pendulum of history, as we see that the Delhi Sultanate and the Mughul Empire were also fragmented.

A federal arrangement could have contained both impulses, centripetal and centrifugal, whereby the course of South Asian history would have been more stable, culturally more productive, with its defense system against invasion enhanced. The medieval period saw the influence of Muslim philosophy, which barring the first philosopher Ya'qub ibn Is'haq al-Kindi began as a quest for the perfect polity. These works being derived from Greek philosophy had as their models the city state as can be seen from the title of two works by Abu Nasr alFarabi: The Principles of the Opinions of the Inhabitants of the Virtuous City and The Political Regime. With the city-state as the unit of study, the federal example fell far beyond its pale.

Since the time of Amir Mahmud of Ghazni, strong regional sultans paid lip service to the increasingly powerless Abbasid caliphs. Thus in theory at least, Muslim polity became a confederation; but it could not progress beyond this point, because its Universal State---the Caliphate--- had been divided by three contemporary dynasties: the Abbasids, the Fatimids and the Umayyads. The devolution of power that the setting up of a federation would require would hardly be forthcoming in the medieval period. At that, time delegation would lead inevitably to secession.

The federal principle entered political discourse due to the presence of the British in India. The Confederation during the American War of Independence, the structure of the Austria-Hungary Empire, began to suggest themselves as a possible solution during the Freedom Movement. However, before we go on to discuss the idea of federation in Western political thought; it is tempting to give an outline of the Christian Republic as espoused by Pierre du Bois (c.1250-1320). The point of interest is that du Bois was anti-clerical, and yet the protagonist of a Christian state. While he was a courtier of King Philip the Fair of France, he wrote polemical tracts against Boniface, the Pope of Rome. The larger mission of Pierre du Bois was to reclaim the Holy lands from the Saracens. 
For this, he proposed a union of what he himself called "sovereign states". He also proposed that since kings were more vigorous, they, and not the generally old popes would lead the Council to be formed. Pierre du Bois proposed the name of the King of France to head the Christian Republic. This arrangement would be subject to an Arbitration Council headed by His Holiness the Pope. The powers unwilling to accept its judgments would be subject to Papal Excommunication. Thus what du Bois envisaged was an executive headed by a monarch and a judiciary headed by a pope. This is what du Bois meant by a Republic.

The Christian Republic of Pierre du Bois remained hypothetical. Why it is deem worthy of mention here is because even now, we see religion in the nooks and corners of political discourse. See for example, this observation of Daniel J. Elazar:

In most of the member states of the European Union, especially the founding members, one finds that the majority came out of the Catholic cultural tradition, and the Protestant states of Europe have not joined. Therefore, the philosophical struggles of the Union are derived principally from the Catholic intellectual experience. 1

Whatever the basis of such observation, it could not be ignored because it proceeds from a Western writer. Nevertheless, there is nothing to suggest that the Catholic experience was anything more than incidental. Let us go back a little to $1683 \mathrm{CE}$ when Pierre Joseph Proudhon wrote his Du Principe Federative, wherein he recommended formation of average size states, and then to unite them in pacts of federation. ${ }^{2}$ Let us come quickly then to the form of federation, and where within it, the focus of power lies. The authors of The Federalist Papers:

Explained the modern idea of 'federation', comprising not a confederation, not a league, but a novel harmony and reconciliation of local and national sovereignties. Federalism is the chief American contribution to the art of government. ${ }^{3}$

As for the second point, the editors of The Federalist Vision show that the location of authority can be either internal, or external:

1 Daniel Elazar, "European Union : A Post-Modern Federation" in Kalyps Nocoladis and Robert Howse (eds) the Federalist Vision, Oxford University Press, 2001, p.45

2 Pierre Joseph Proudhon, cited in Dusan Sidjanski, The Federal Future of Europe, Ann Arbor, The University of Michigan Press, 2000, p.189

3 Marshall Smelser, American History at a Glance, New York, Barnes and Nobel, 1966, pp.44-45 
If the federation is no more than the sum of its parts, it is really just a confederation, or league, with each member having a veto over sovereign acts of the centre, and acting autonomously on the world stage. If the federation is more than the sum of its parts, then a majority of the whole may prevail over the will of any of its parts, which make federalism often seem like central government, with administrative decentralization. 4

We need to look at the difference between American and European unions, and then, we can go into the question of why federations or confederations at all come into being. There is a judgment of the United States Supreme Court ( Printz vs. United States 521 U.S. 898 1997) according to which the federal government cannot commandeer state governments into implementing federal policy. On the other hand, the founding charters of the European Union and Germany permit commandeering. It is on this principle that the powers of the directly elected European Parliament, according to Andrew Moravesic, steadily increased during the decade from 1991 to 2001.5

Thus the European progress from city-state to federation is due to long, rather prolonged experiments with forms of government, intersecting with changes in the extent of empires and principalities, culminating in the Treaty of Westphalia (1648 $\mathrm{CE}$ ). The bare fact that the nation state emerged from a 30 years sectarian conflict, shows that the political leaders of Europe were using the sliding rule to arrive at a point they hoped would ensure the longest spell of peace. Federalism, despite the number of islands could not have grown out of the city-state.

Although in America, the Articles of Confederation saw the War of Independence to a close, they were unable to solve the problems of commerce that had been created. That is why Alexander Hamilton, when he formulated on 18 December $1787 \mathrm{CE}$, the principles and functions of a federation, gave commerce an almost equal status as defense and foreign relations:

The principle purposes to be answered by Union are these--- the common defense of the members--- the preservation of public peace as well against internal convulsions as external attacks---the regulation of commerce with other nations and

Kalyp Nicoladis and Robert Howse, op. cit.p.2

Andrew Moravesic, "Federation in the European Union", Ibid. p.162. 
between states, the superintendence of our intercourse, political and commercial with foreign countries. ${ }^{6}$

Therefore, whatever the imperatives of an evolutionary course, whatever pitfalls federation had encountered in the Western hemisphere, the concept had visible attractions for the people of British India, who were struggling to put together a configuration of their own. The colonial empire consisted of a British crust, ruling over a Hindu majority and a Muslim minority. Initially because of a cadre of liberal and enlightened politicians including Gopal Krishan Gokhale (1866-1915 CE) and Chita Ranjan Das (1870- 1925 CE) there were bright chances that an Indian Federation would evolve by arriving at a mutually agreed formula and living happily ever after.

Well, we did not and that is why we are here, but we must simultaneously emphasize that it was because of communalism, and not because of the Hindu creed that we failed. G.K. Gokhale took Muslims along, rendering them sincere advice; while C. R. Das broadcast that, his concessions to Muslims under the Bengal Pact was made because he was a Hindu. In doing so, he had to contend with the Congress, and had he, the Deshbandhu prevailed over Congress there would be no room in history for a Bangabandhu.

Here, we must consider this dictum of Jaques Delors: "The logic of federalism has, in fact been present at all the main stages of European integration". ${ }^{7}$ There is of course logic to federalism, but it is different with regard to Europe and South Asia. The British considered the federal option because they had to effect a compromise between the Congress, that wanted power located in the Centre and the Muslim League that wanted power to be located in the provinces. Then, there was also another entity, in the shape of the Princely States that had to be accommodated while the British occupied India.

The main consideration guiding the Muslim League, whenever it approached federation was defense. This is not surprising and perhaps reflects the logic of federalism of which Jaques Delors had written. This springs from the relative importance imbued by the authors of The Federalist Papers to what they termed the causes of federation; Defense, Foreign Affairs and Commerce. James Madison advised that if defense dictated, units should accept federation, even though the units receive them unequally. ${ }^{8}$

\footnotetext{
Alexander Hamilton,, The Federalist Papers, No.27

Jaque Delors, Introductory Note to Dusan Sidjanski, op.cit. p. IX

8 James Madison, The Federalist Papers, New York, The New American Library of World Literature, 1961, p.44
} 
Perhaps the rulers in independent Pakistan took this to heart, when they, from the beginning, brought in considerations of defense to abridge the powers of the provinces. However, we are getting ahead of ourselves. As Matlubul Hasan Saiyid recounted, until 1913, the Muslim League desisted from placing before itself any model "either on the lines of Western institutions or otherwise, for the future constitution of India'. In the next document produced, in the 'Memorandum of the Nineteen', on the initiative of Mohammad Ali Jinnah, this term does surface:

In any scheme of Indian Federation, India should be given, through her chosen representatives, a place similar to that of the self-governing Dominions.

The provincial Governments should be made autonomous as stated in the Government of India's Dispatch dated 5 August 1911.10

A word of caution is in order regarding the chronology. This Memorandum was formulated in 1916 but was formally submitted to the Government of India on 22 April 1918. Although initiated by Jinnah who had come to play an equally important role in the Congress and the Muslim League, it cannot as such be called a Muslim League document. In the 1916 Lucknow Pact, a federal arrangement was something akin to an assurance The Pact was that the Muslim League would make selfgovernment its ideal, while the Congress would give its consent to Separate Electorates for the Muslims. This was a delicate point, since not only Congress leaders but also Muslim leaders like M. A. Jinnah and Liaquat Ali Khan had made speeches against Separate Electorates; but on no other basis would Muslims, already disturbed by the repeal of the Partition of Bengal (1905) agree.

The resolution then stated that the provincial legislative councils shall consist of four- fifth elected and one-fifth nominated members---the members of Council should be elected directly by the people on as broad a franchise as possible. Adequate provision should be made for the representation of important minorities by elections and Musulmans should be represented through Separate Electorates.

"The Government of India shall not ordinarily interfere in the local affairs of a province, and powers not specifically given to a provincial government, shall be deemed to be vested in the former." 11 These were the actual though faltering steps towards federation. The Lucknow Pact was a break through and it was expected that with time, communal harmony would solidify and lead a united India to freedom, but then, against the advice of M.A. Jinnah, the Muslim League, and in concert, the

9 Matlubul Hasan Saiyid, Mohammad Ali Jinnah : A Political Study, Lahore, Muhammad Ashraf, 1945, p.84

$10 \quad$ Ibid. p. 822

$11 \quad$ Ibid. p.899 
Congress took up the Khilafat Cause. With the political process disrupted, Jinnah sidelined, and Mahatma Gandhi leading the Khilafat Movement, India suffered a surfeit of harmony. Leaders such as Dr. Saifuddin Kitchlew said there was no further need for Separate Electorates! Congress leaders did not lag behind, and the only tangible result of the Khilafat Movement was that the Lucknow Pact was unraveled.

Jinnah was not disheartened. For him Separate Electorates were not a personal loss and he sat down to negotiate with the Congress another constitutional agreement; this time, based on Joint Electorates. On 20 March 1927, Jinnah released the Delhi Muslim Proposals. In return for giving up Separate Electorates, the Muslim League demanded the separation of Sindh from Bombay Presidency, and the elevation of the N-W.F.P and Balochistan to the same status as enjoyed by the other provinces. Both Hindus and Muslims would make concessions to minorities in their provinces on a reciprocal basis. In the Central Legislature, Muslim representation would not be less than one-third based on Joint Electorates.

These proposals had attractions for both communities and the Congress accepted them on 16 May 1927. There were some objections from the Mahasabha and the Hindu press, and to meet them, Jinnah made an elaboration of his points on 30 May. In the December Madras 1927 Congress Session, the acceptance of the Delhi Muslim Proposals were ratified. The text did not carry the word 'Federation' but 'Centre'. Nevertheless, since the scheme was based on creating more Muslim majority provinces and enhancing their status, it is being treated as a federal scheme.

It was at this juncture that the British played the spoilers. On 8 November, they had announced the creation of a statutory commission under Sir John Simon. When Jinnah protested that the Commission had no native member, the Secretary of State, Lord Birkenhead riposted that if a Hindu had been appointed, Muslims would protest and vice versa. Jinnah, not aware that Lord Birkenhead privately agreed with him, went on the warpath. Secure in his knowledge that the Hindus and Muslims already had a constitutional agreement and only dotting the eyes and crossing the tees was left, Jinnah accepted Birkenhead's challenge and became determined to prove that Indians were capable of producing their own constitution. For this purpose, a Commission was formed under Jinnah's close friend, Motilal Nehru.

Notwithstanding its unpopularity, even boycotts in various parts of India, the Simon Commission did publish its recommendations. It considered a federation at the Centre bringing together the provinces of British India and the Princely States. Internally, both entities retained their autonomy. The Simon Commission Report was not placed before the British Parliament, but was consulted while the Round Table Conferences were in progress. Moreover, when the Government of India Act 1935 was being framed, the Nehru Report did not do fare better, for when it was published all safeguards under the Delhi Muslim Proposals were removed. 
After all Jinnah's efforts to have some of the safeguards restored, could not succeed, he came out with his famous 14 Points; the first one of which stated: "The form of the future constitution shall be federal, with the residuary powers vested in the provinces." 12

By this means, Jinnah hoped to salvage some of the gains made through the Delhi Muslim Proposals. In fact, the Muslims of the majority provinces who really had a thin majority had not been prepared to give up Separate Electorates, therefore the 14 points were the Delhi Muslim Proposals in addition to Separate Electorates. The GOI Act 1935 provided for a federation similar to that recommended by the Simon Commission, with enhanced provincial autonomy.

The federal part never came into operation because the major parties would not join. Only the provincial portion came into operation. Under the GOI Act 1935, elections were held despite the provision of Separate Electorates, the Muslim League lost; that is the electorate rejected the Muslim League. For details about the resurgence of the Muslim League, I refer you to my monograph on the Raja of Mahmudabad. ${ }^{13}$

The two-year experience of Muslims under Congress rule finally convinced them of the need of a separate state of their own, and that a federation would be inadequate to secure them their basic rights. Even Lord Mountbatten conceded this. ${ }^{13}$ In April 1939 Jinnah said in Delhi that, "In regard to Federation, there were several schemes in the field, including dividing the country into Hindu India and Muslim India."14

Quite evidently, federal schemes were now abandoned in favor of division. The Lahore Resolution demanded geographically contiguous units that would be "Autonomous" and "Sovereign.". Now autonomous and sovereign are mutually exclusive terms: especially in the context of a federation where rights need to be delegated. Qurat-ul-Ain Hyder conveyed to me that, Sajjad Hyder Yildarim, her father, had drafted Jinnah's speech of Lahore 1940. However, the resolution was not, and the ambiguity must have been deliberate.

Now Jinnah became adamant, and was not prepared to consider the option of a federation. In 1943, he was most emphatic in its rejection and the word "autonomous" must have been imbued with a particular meaning to which we shall presently return. .Jinnah said: "Federation however described and in whatever

Hamid khan, Constitutional and Political History of Pakistan, Karachi: OUP,2005,p.17

13 Muhammad Reza Kazimi, The Raja of Mahmudabad : A Political Study, Karachi, SAMA, 2015

14 Larry Collins and Dominique Lapierre, Mountbatten and the Partition of India, Colombo, People's Publishing House, 1982, p.22 
terms it is put, must ultimately deprive the federating units of authority in all vital matters."15

Jinnah's aspect was forbidding, nevertheless, in considering the fate of millions, he unbent. Although Jinnah's reply to General Sir Arthur Smith, who pleaded that Division would hamper defense, was discouraging, this evidently weighed with him. Submitting the All-India Muslim League constitutional proposals to the Cabinet Mission on 12 May 1946, he acceded to a common Centre above Hindu and Muslim groups of provinces. Jinnah said that the Centre should deal only with Foreign Affairs, Defense and Communications pertaining to Defense. His stipulation was that the Centre would be in the nature of a managing agency, have no legislature and no powers of taxation. ${ }^{16}$

The Cabinet Mission would not agree and in their own scheme, known as the State Paper of 16 May 1946, they said that the Centre would have both a legislature and powers of taxation. Thus, the Cabinet Delegation turned the federal scheme of the Muslim League into a Federal system. There would be one large Hindu group and two smaller Muslim groups of provinces. Against the written advice of Liaquat Ali Khan sent on 21 May, Jinnah accepted the Cabinet Mission Plan. ${ }^{17}$ Liaquat's main objection was that the coercive apparatus of the state would remain with Congress, and in time, it would remove all the safeguards for which the Muslim League was foregoing a sovereign Pakistan. In view of Jinnah's 1943 statement, we can be sure that the point had not escaped him; yet he was prepared to give federation a chance. There is one significant reservation: the 12 May Proposals did not delegate Finance.

When, on 10 July 1946 Jawaharlal Nehru resiled from the Grouping clause, Sardar Patel had called it 'emotional insanity'. Now deprived of choice, the Muslim League withdrew its acceptance of the Cabinet Mission Plan. What did the word "autonomous" in the Lahore Resolution mean? In early 1947, Huseyn Shaheed Suhrawardy, Kiran Shankar Roy and Sarat Chandra Bose devised a scheme of a united and sovereign Bengal. M.A. Jinnah agreed. ${ }^{17}$ M. K. Gandhi agreed, but had to withdraw when he was taken to task by the Congress Working Committee. ${ }^{18}$

Pundit Jawaharlal Nehru said that, "There was no chance of the Hindus there agreeing to put themselves under permanent Muslim domination." ${ }^{19}$ When it suited

15 Khalid B. Sayeed, Pakistan : The Formative Phase, Karachi, Oxford University Press, PB, 1969, p.108

16 Jamil Ud-Din Ahmad (ed.) Speeches and Writings of Mr. Jinnah, Lahore, Muhammad Ashraf, 1968,Vol.I, p.530

17 Muhammad Reza Kazimi, Liaquat Ali Khan :His Life and Work, Karachi, Oxford University Press, 2003, pp.159-161

18 H.V. Hodson, The Great Divide, Karachi, Oxford University Press. 1989, p.246

19 Joya Chatterji, Bengal Divided, New Delhi, Cambridge University Press, 1996, p.260 
him, Jawaharlal Nehru could also espouse the Two-Nation Theory. As for Sardar Patel,it is Sheikh Mujibur Rahman who tell us that "Apparently Sardar Vallabhai Patel had told him 'Mr. Bose stop acting crazy; we want Calcutta' 20 why they wanted Calcutta is made plain by this plaint of Dhirendra Nath Dutta: "Sir, Bengal has been divided, but the trade Centre continues to be Calcutta. People living in Eastern Bengal have got their connections with Calcutta which can never be broken."21

How seriously and till how late the United Bengal scheme had been pursued can be gathered from a recently de classified document dating $2^{\text {nd }}$ June 1947 which reveals that the British Prime Minister Clement Atlee had expected Bengal to emerge as a separate country. ${ }^{22}$

While, under the Lahore Resolution, Jinnah could allow Bengal sovereignty, as there was no constitutional device by which he could refuse the_accession of East Bengal. It was this province, which delayed and confounded attempts at federation in Pakistan. One hope lay in the Mohammad Ali Formula, which provided for a bicameral legislature to prevent any one wing dominating, but it came to nothing. An inherent resistance against the concept of federalism was witnessed, when in 1955, One Unit came into being by merging the four provinces of West Pakistan. This led not to federation but polarization between the wings. One-Unit continued under the 1956 and 1962 constitutions.

Since the Indian Independence Act 1947 followed the contours of the Government of India Act 1935, federation had to be introduced. In 1935 because of the opposition of the Prices and leading parties, its federal portion did not come into operation, but on Independence, there was no impediment, but within the first decade of Pakistan's coming into existence, Liaquat Ali Khan's resolution that 'Pakistan shall be a federation, our geography dictates that' had been left behind. Both the 1956 and 1962 constitutions failed because of Parity and One-Unit. One must admit that the Pakistan Movement having guided by a constricted system of franchise, universal suffrage was delayed in Pakistan. The framing of constitutions became a contentious and ultimately futile exercise.

The 1970 elections based on direct adult franchise proved disastrous, just because General Yahya Khan shied away from imposing the condition of two-third majority for framing the constitution. He considered a 60 per cent majority, but that too was dropped on 25 November 1969. As G.W. Choudhury reveals, "At the eleventh hour,

20 S. M. Burke and S.A.D. Qureshi, The British Raj in India, Karachi, Oxford University

21 Sheikh Mujibur Rahman, The Unfinished Memoirs, Karachi, Oxford University Press, 2012, p.78

22 Dhirendra Nath Dutta, The Constituent Assembly (Legislature) of Pakistan Debates, Karachi, Vol .I, 1948, p.237 
by most skillful maneuvering, Yahya dropped the clause from the plan."23 Thus, from 1969 to 1972 Pakistan had no constitution, only a basic law in the shape of Martial Law. The Federal Republic of Germany also, till re-unification had no constitution only a basic law. Z.A. Bhutto could not have taken over as President unless he had also taken over as the Chief Martial Law Administrator. While there was a constitutional void in Pakistan, no negotiated transfer of power could take place without unraveling the constitutional basis of West Pakistan. The Interim Constitution was enacted on 14 April 1972, while the permanent constitution was promulgated on 14 August 1973. The very first Article stated, "Pakistan shall be a Federal Republic to be known as the Islamic Republic of Pakistan." 24

23 Dawn,28 December 2018,p.14

24 G.W. Choudhury, The Last Days of United Pakistan, Karachi, Oxford University Press, PB 1998, p.87 
Jhss, Vol. 10, No. 1 , January to June, 2019

\section{References}

Andrew Moravesic, "Federation in the European Union"

Alexander Hamilton, The Federalist Papers, No.27

Daniel Elazar, “European Union: A Post-Modern Federation” in Kalyps Nocoladis and Robert Howse (eds) The Federalist Vision, Oxford University Press, 2001

Dhirendra Nath Dutta, The Constituent Assembly (Legislature) of Pakistan Debates, Karachi, Vol .I, 1948

Dawn, 28 December 2018

G.W. Choudhury, The Last Days of United Pakistan, Karachi, Oxford University Press, PB 1998

Hamid khan, Constitutional and Political History of Pakistan, Karachi: OUP, 2005

H.V. Hodson, The Great Divide, Karachi, Oxford University Press. 1989

James Madison, The Federalist Papers, New York, The New American Library of World Literature, 1961

Jamil Ud-Din Ahmad (ed.) Speeches and Writings of Mr. Jinnah, Lahore, Muhammad Ashraf, 1968,Vol.I

Joya Chatterji, Bengal Divided, New Delhi, Cambridge University Press, 1996

Khalid B. Sayeed, Pakistan : The Formative Phase, Karachi, Oxford University Press, PB, 1969

Larry Collins and Dominique Lapierre, Mountbatten and the Partition of India, Colombo, People's Publishing House, 1982

Marshall Smelser, American History at a Glance, New York, Barnes and Nobel, 1966

Matlubul Hasan Saiyid, Mohammad Ali Jinnah : A Political Study, Lahore,

Muhammad Ashraf, 1945

Muhammad Reza Kazimi, The Raja of Mahmudabad : A Political Study, Karachi, SAMA, 2015 
The Evolution of Federalism as a System of Governance in South Asia: A Historical Appraisal

Muhammad Reza Kazimi, Liaquat Ali Khan :His Life and Work, Karachi, Oxford University Press, 2003

Pierre Joseph Proudhon, cited in Dusan Sidjanski, The Federal Future of Europe, Ann Arbor, The University of Michigan Press, 2000

S. M. Burke and S.A.D. Qureshi, The British Raj in India, Karachi, Oxford University

Sheikh Mujibur Rahman, The Unfinished Memoirs, Karachi, Oxford University Press, 2012 